\title{
Selection of the Elite Lines with High Adaptability to Autumn Sowing of South Korea in Faba Bean
}

\author{
Min-Kyu Lee ${ }^{1,2}$, Dong-Gun Kim ${ }^{1,3}$, Jung Min Kim ${ }^{1,2}$, Jaihyunk Ryu ${ }^{2}$, Seok Hyun Eom ${ }^{4}$, Min Jeong Hong ${ }^{1}$, \\ Young Eun Jang ${ }^{1}$, Bo-Keun $\mathrm{Ha}^{2} *$, Soon-Jae Kwon ${ }^{1 *}$ \\ ${ }^{1}$ Advanced Radiation Technology Institute, Korea Atomic Energy Research Institute, Jeongeup 56212, Korea \\ ${ }^{2}$ Division of Plant Biotechnology, Collage of Agriculture and Life Science, Chonnam National University, Gwangju 61186, Korea \\ ${ }^{3}$ Department of Life-resources, Graduate School, Sunchon National University, Sunchon 59722, Korea \\ ${ }^{4}$ Department of Horticultural Biotechnology, College of Life Sciences, Kyung Hee University, Yongin 17104, Korea
}

\begin{abstract}
This study involved an evaluation of agronomic characteristics to identify elite faba bean (Vicia faba L.) lines adapted to the environmental conditions in Korea. A total of 371 accessions were sown in February 2015, and 256 lines among 1,006 individuals were selected based on seed size and color as well as seed yield per plant. Thirty seeds of each line were sown in October 2015 to analyze the winter survival rates and agronomic characteristics. The 129 lines that survived until March were examined based on nine traits, including flowering date, plant height, number of stems, pot length, pot width, seeds per pot, 100-seed weight, seed size and seed color. Finally, ten elite lines were selected according to the winter survival rate, seed size and color, as well as seed yield per plant. Green seeds were observed for four of the selected lines, brown seeds were observed for two lines, and black, purple, and beige seeds were detected in one line each. The average winter survival rate was $74.8 \%$. Moreover, the average plant height and 100 -seed weight were $83.5 \mathrm{~cm}$ and $10.8 \mathrm{~g}$, respectively. The plants produced an average of 150 seeds. These results will be very useful for autumn-sown of faba bean in South Korea, and ten elite lines will provide great opportunity for faba bean breeding.
\end{abstract}

Keywords Faba bean, Autumn-sown, Winter-survival rate, Elite lines

\section{INTRODUCTION}

Faba bean (Vicia faba L.), which is also called broad bean and horse bean, is an agriculturally important crop worldwide because it represents a source of fixed nitrogen and is useful to animals and humans (Duc 1997; Zong et al. 2009). The large-seeded faba bean is used as food, the medium-sized faba bean is used as food and feed, and the small-seeded faba bean is mostly used as feed (Redden et al. 2007). Faba bean is consumed as food and feed in several countries, including China, Morocco, Ethiopia, Sudan, Egypt, and Australia (Singh et al. 2009). China is the largest faba bean-producing country, responsible for
$34.5 \%$ of the global production, followed by Ethiopia, Australia, France, Morocco, Sudan, Egypt, the UK, Germany, Peru, and Italy (FAO Statistical database, http://www.fao.org). Despite the considerable faba bean production in Asia, there is currently no cultivar that was developed in Korea, although some varieties have been imported from China (Korea Seed \& Variety Service, http://www.seed.go.kr).

Faba bean is rich in sugars and nutritionally valuable compounds, including protein, fat, fiber, carbohydrates, and vitamins A, B1, B2, and C. Moreover, faba bean contains L-DOPA (L-3,4-dihydroxyphenylalanine), which is a precursor of dopamine, and is a common ingredient in

Received January 25, 2018; Revised February 14, 2018; Accepted February 19, 2018; Published March 1, 2018

*Corresponding author Soon-Jae Kwon, soonjaekwon@kaeri.re.kr, Tel: +82-63-570-3312, Fax: +82-63-570-3814

*Comesponding author Bo-Keun Ha, bkha@jnu.ac.kr, Tel: +82-62-530-2055, Fax: +82-62-530-2059 
prescription drugs used to treat Parkinson's disease (Randhir and Shetty 2003; Hu et al. 2015).

Faba bean can be divided into spring-sown and autumn-sown ecotypes according to cold tolerance as well as factors delimiting sowing time and the target climatic zone (Lawes et al. 1983; Chen et al. 2006). Autumn-sown faba bean offers the agronomic advantages of winter crops, including increased probability of good sowing conditions, good root establishment, longer growth cycle, earlier flowering and seed-filling period, escape from summer drought stress, and early maturity (Flores et al. 2012). However, the main disadvantage of autumn-sown faba bean is the risk of winter kill by cold temperatures. Autumn-sown faba beans survive the winter as young plants. In cool-temperate climates, faba bean is grown as a spring crop that is not damaged by temperatures as low as $-6^{\circ} \mathrm{C}$. However, there is insufficient cold-tolerant faba bean germplasms, and the flowers are not frost-resistant (Link et al. 2010). Autumn-sown faba beans cultivated in oceanic and continental areas require increased frost tolerance, often undergo a freeze-thaw cycle, and are exposed to long-term snow cover in some regions (Duc 1997). The climate in South Korea during the 1970s and 1980s was not suitable for cultivating winter faba bean and it was possible to cultivate only some regions (Kim 2006). Nevertheless, the regions in which faba bean can be cultivated may be expanded by breeding new varieties exhibiting enhanced overwintering survival and winter hardiness.

Cultivating faba bean by transplanting seedlings offers more advantages than direct seeding, including higher yield and winter survival rate, early flowering, and earlier harvest (Kim 2006). Additionally, the benefits of applying mulching materials during cultivation include an earlier harvest, higher overall yield, decreased evaporation, fewer weeds, decreased drowning of crops, cleaner products, and decreased fertilizer leaching (Tachibana 1981; Nyoike and Liburd 2010). Faba bean plants cultivated with mulching materials flower earlier and produce higher yields than plants cultivated without applying a mulching material (Kim 2006).

In this study, we test of 256 lines were planted in mulching and non-mulching fields to investigate the winter survival rate, plant height and flowering date for domestic adaptability. With the advent of climate change and some improvement of winter hardiness and freezing resistance, the zone of adaptation of autumn-sown faba bean is expected to expand to more north regions in South Korea. The purpose of this study was to survey 371 genetic resources (i.e., germplasm) collected worldwide for the subsequent development of new faba bean varieties adapted to the environmental conditions in South Korea.

\section{MATERIALS AND METHODS}

\section{Plant material}

We received 371 faba bean accessions from the Western Regional Plant Introduction Station of the United States Department of Agriculture-Agricultural Research Service. Spring-sown faba bean plants were used to analyze faba bean characteristics. Three seeds for each accession were sown in a greenhouse on February 2, 2015. Autumn-sown faba bean plants were used to identify winter-hardy germplasm. A total of 256 plant lines were tested, with 30 seeds per line sown in pots and grown in a greenhouse on October 15, 2015. Healthy 4-week-old seedlings were transplanted to an experimental field at the Korea Atomic Energy Research Institute (KAERI) in Jeongeup, Korea $\left(35^{\circ} 30^{\prime} \mathrm{N}, 126^{\circ} 49^{\prime} \mathrm{E}\right)$. Polyethylene mulch material was applied to the field.

\section{Weather conditions}

During the study period, the temperature and rainfall were recorded at a weather station located at the experimental field. The 30-year average temperature at Jeongeup was provided by the Korea Meteorological Administration. The temperatures recorded at the experimental field from October 2015 to June 2016 were compared with the 30 -year average temperature in winter.

\section{Trait survey}

There are no standard or recommended faba bean varieties in Korea. Thus, the Gungang Jamdu cultivar imported from China and marketed in Korea was used. Faba bean traits were surveyed according to the soybean 
form from the Agricultural Science and Technology Research Survey (Korea Seed \& Variety Service). The following traits were assessed for 256 faba bean lines: winter survival rate, flowering date, plant height, number of stems (including tillers more than half the length of the main stem), and pod length and width. Additionally, seed size and color, 100-seed weight, and seed yield per plant were examined after beans were harvested.

Winter survival rate: percentage of plants that survived the winter

Flowering date: date on which $50 \%$ of the plants had at least one flower

Plant height: distance from the soil surface to the tip of the uppermost leaf in medium-sized plants (calculated based on three replicates)

Number of stems: main stem plus the tillers taller than half the length of the main stem (calculated based on three replicates)

Pod size: length and width measured with a veneer caliper and ruler (calculated based on three replicates)

100-seed weight: weight of 100 randomly selected seeds (calculated based on two replicates)
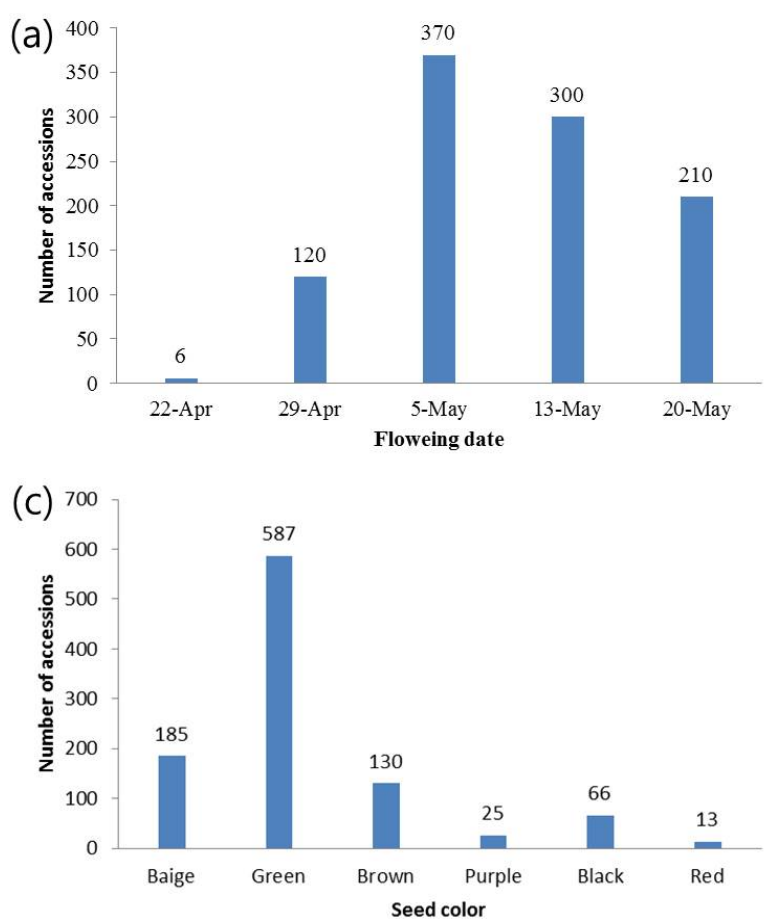

\section{Statistical analysis}

Agronomic characteristics (e.g., plant height, number of tillers, and pod length and width) were analyzed using three replicates. Correlations were determined based on Pearson's correlation coefficients. Data underwent an analysis of variance using the SPSS program (version 22) (SPSS Inc., USA).

\section{RESULTS}

\section{Agronomic characteristics of spring-sown faba bean gemplasm}

We surveyed 1,006 individual plants after sowing the seeds of 371 accessions in February 2015 to select elite individuals suitable for cultivation in Korea. We evaluated agronomic characteristics (i.e., flowering date, seed color, seed size, and seed yield per plant) of all 1,006 plants (Fig. 1). The flowering date ranged from April 22 (6 plants) to May 20 (210 plants), with 370 and 300 plants that were flowered on May 5 and May 13. 2015, respectively.
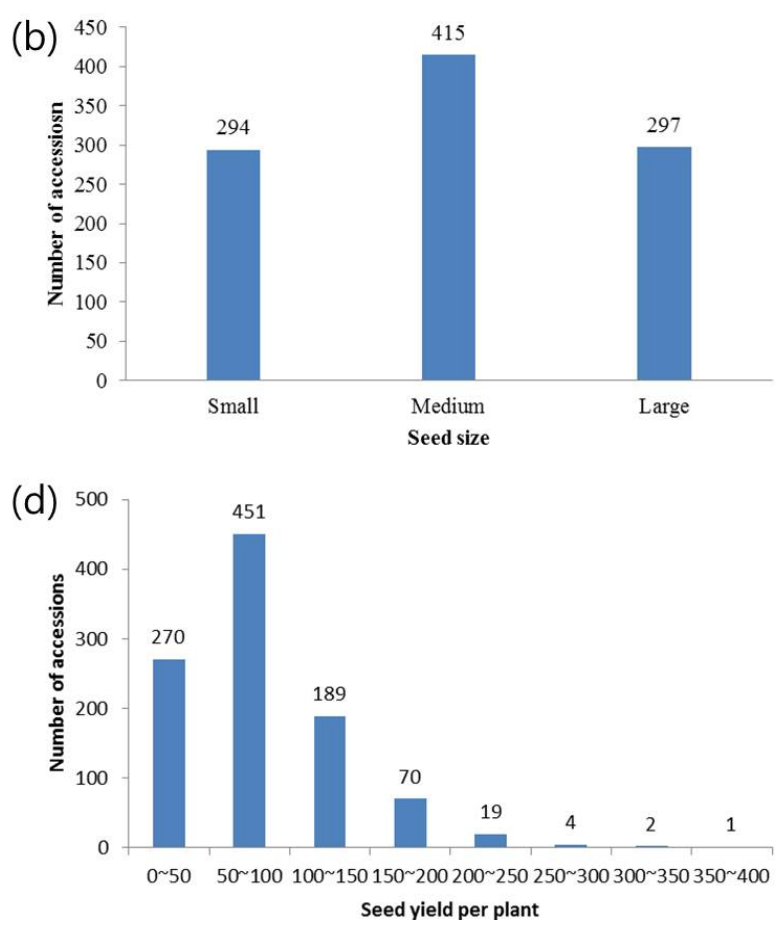

Fig. 1. Agronomical characteristic of 1,006 individuals with spring-sown faba bean. (a) flowering date, (b) seed size, (c) seed color, (d) seed yield per plant. 
Additionally, we observed that $185,587,130,25,66$, and 13 plants produced seeds that were beige, green, brown, purple, and black, respectively. Moreover, the seeds of 294, 415, and 297 plants were small, medium, and large, respectively. The seed yield per plant ranged from 9-395, with an average of 82 . A total of 256 lines were selected based on the seed yield per plant, various seed size and seed color. We subsequently investigated the faba bean growth characteristics with specific mulching conditions.

\section{Weather conditions}

The average monthly temperatures at the experimental field were recorded as $6.7^{\circ} \mathrm{C}(\mathrm{Dec}), 2.2^{\circ} \mathrm{C}(\mathrm{Jan})$, and $5.1^{\circ} \mathrm{C}$ (Feb), which were higher than the average temperature for the region. However, the minimum recorded temperatures for the experimental field were $-2.8^{\circ} \mathrm{C}(\mathrm{Dec}),-6.7^{\circ} \mathrm{C}(\mathrm{Jan})$, $-3.7^{\circ} \mathrm{C}$ (Feb), which were lower than the average temperature for the region. Additionally, the lowest temperature during the cultivation period was $-11.3^{\circ} \mathrm{C}$, which was recorded on January 26, 2016 (Table 1).

\section{Agronomical characteristics of autumn sowing lines}

The 256 faba bean lines selected based on their traits were sown on October 15, 2015 to select lines with superior winter survival rates and excellent agronomic traits. Of these 256 lines, 26 were from Iran, 18 were from Spain, 14 were from Turkey, 13 were from Hungary, 11 were from the United States of America, nine were from Peru and Ethiopia, seven were from the United Kingdom, Morocco, France, and China, five were from the former Serbia and Montenegro, four were from Kenya, the former Soviet Union, Egypt, and Afghanistan, three were from Pakistan,
Nepal, Canada, and Bulgaria, two were from Sudan, Poland, Italy, India, Finland, and Ecuador, and one was from Syria, Sweden, New Zealand, Mexico, Lebanon, Japan, Colombia, Chile, Bolivia, and Argentina. We observed that 129 lines survived until March 2016. However, most of the surviving lines had a winter survival rate that did not exceed $60 \%$, with an average of $35.3 \%$. Only 20 lines had a winter survival rate greater than $60 \%$, while only four lines had a winter survival rate that exceeded $80 \%$ (Fig. 2).

The agronomic characteristics of the 129 lines that survived until March 2016 are listed in Supplementary Table S1. The plant height ranged from 44.3 to $116 \mathrm{~cm}$, with an average of $78.8 \mathrm{~cm}$. There were 57 lines that were $60-80 \mathrm{~cm}$ tall, 55 lines that were $80-100 \mathrm{~cm}$ tall, and seven lines that were taller than $100 \mathrm{~cm}$ (Fig. 3). The flowering date for the autumn-sown faba bean lines ranged from March 29 (22 lines) to April 26 (seven lines). With 31, 29, and 40 lines were flowered April 5, April 12, and April 19,

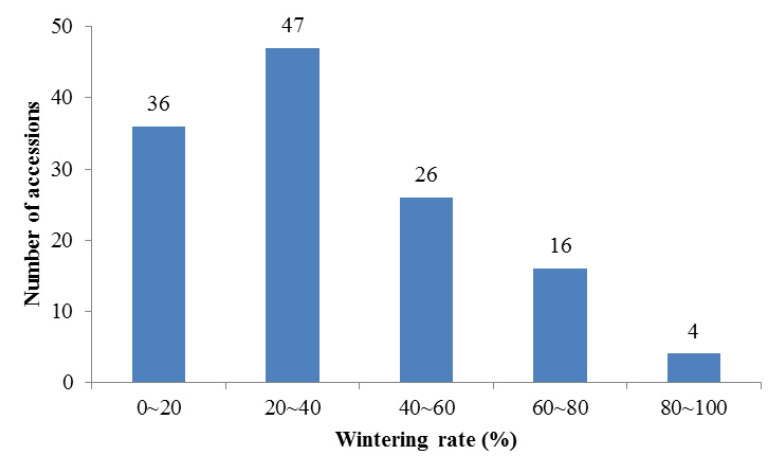

Fig. 2. Frequency distribution of wintering rate of 129 faba bean lines that survived until March, 2016.

Table 1. Average and minimum temperature during winter season in Jeongeup.

\begin{tabular}{|c|c|c|c|c|c|c|c|c|c|}
\hline & & \multicolumn{4}{|c|}{ Average temperature $\left({ }^{\circ} \mathrm{C}\right)$} & \multicolumn{4}{|c|}{ Minimum temperature $\left({ }^{\circ} \mathrm{C}\right)$} \\
\hline & & $\mathrm{F}^{\mathrm{z})}$ & $\mathrm{M}$ & $\mathrm{L}$ & A & $\mathrm{F}$ & $\mathrm{M}$ & $\mathrm{L}$ & A \\
\hline \multirow[t]{2}{*}{ Dec. } & $\mathrm{E}^{\mathrm{y})}$ & 7.4 & 7.7 & 5.0 & 6.7 & -1.3 & -3.8 & -3.4 & -2.8 \\
\hline & $\mathrm{A}$ & 3.7 & 1.9 & 0.9 & 2.2 & -1.0 & -2.4 & -3.5 & -2.3 \\
\hline \multirow[t]{2}{*}{ Jan. } & $\mathrm{E}$ & 5.5 & 2.1 & -0.9 & 2.2 & -2.3 & -6.6 & -11.3 & -6.7 \\
\hline & $\mathrm{A}$ & -0.1 & -0.5 & -1.0 & -0.5 & -4.5 & -4.7 & -5.2 & -4.8 \\
\hline \multirow[t]{2}{*}{ Feb. } & E & 1.6 & 8.3 & 5.5 & 5.1 & -5.7 & -2.6 & -2.8 & -3.7 \\
\hline & A & 0.0 & 1.7 & 2.5 & 1.4 & -4.4 & -2.9 & -2.3 & -3.2 \\
\hline
\end{tabular}

${ }^{\mathrm{z})} \mathrm{F}$ : First ten days, M: Middle ten days, L: Late ten days, ${ }^{\mathrm{y})} \mathrm{E}$ : Experimental field, A: Average for 30 years (1981-2010). 
(a)

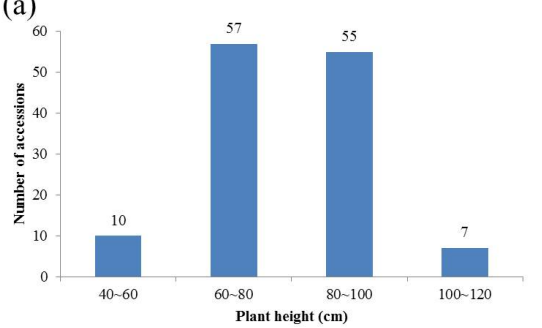

(d)

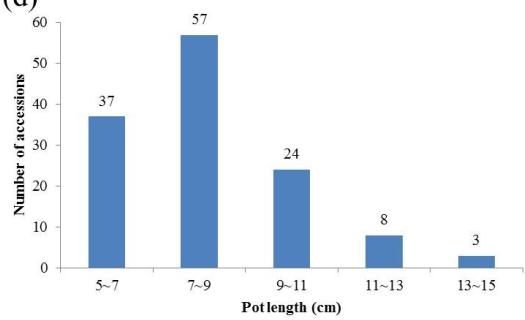

(g)

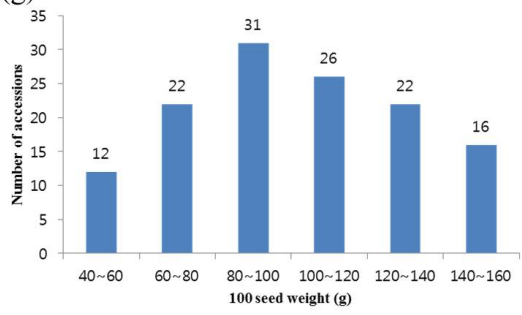

(b)

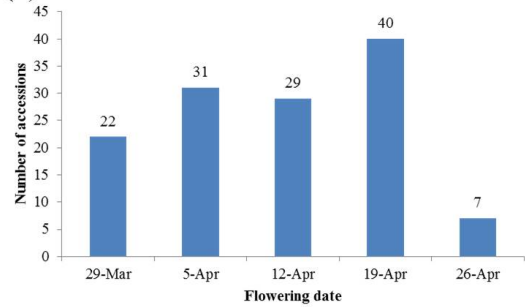

(e)

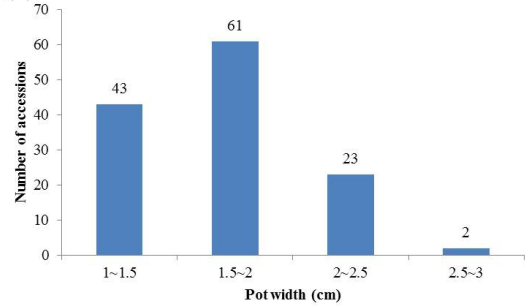

(h)

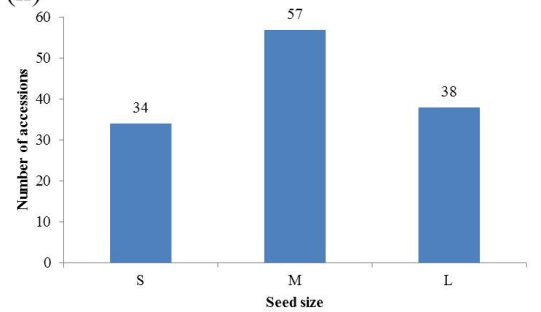

(c)

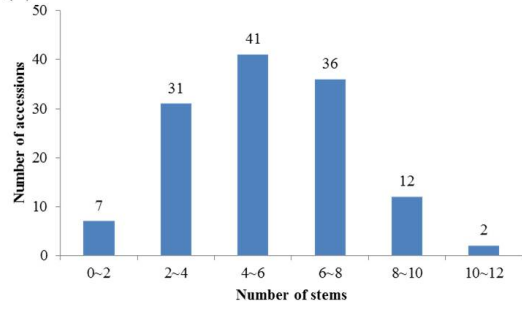

(f)

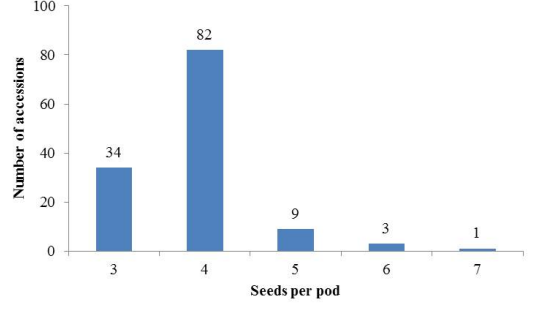

(i)

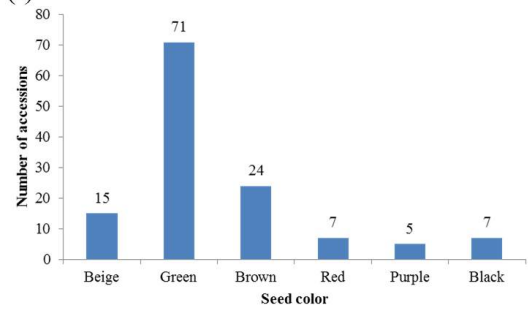

Fig. 3. Agronomical characteristic distribution of 129 lines of autumn-sown faba bean. (a) plant height, (b) flowering date, (c) number of stems, (d) pot length, (e) pot width, (f) seeds per pot, (g) 100-seed weight, (h) seed size, (i) seed color.

respectively. Meanwhile, the number of stems ranged from 1.0 to 11.3 , with an average of 5.2. Specifically, 41 lines had 4-6 stems, 36 lines had 6-8 stems, and two lines had more than 10 stems. Pod length ranged from 5.0 to $14.5 \mathrm{~cm}$, with an average of $8.1 \mathrm{~cm}$. We detected 57 lines with pod lengths of 7-9 cm, 37 lines with pod lengths of $5-7 \mathrm{~cm}$, and three lines with pod lengths exceeding $13 \mathrm{~cm}$. Moreover, pod width ranged from 1.0 to $2.7 \mathrm{~cm}$, with an average of 1.6 $\mathrm{cm}$. There were 61 lines with pod widths of $1.5-2 \mathrm{~cm}, 43$ lines with pod widths of 1-1.5 cm, and two lines with pod widths greater than $2.5 \mathrm{~cm}$. The seeds per pod ranged from 3 to 7, with an average of 3.9. Of the analyzed lines, 87 produced four seeds per pod, 34 produced three seeds per pod, and four produced more than six seeds per pod. The 100 seed weight ranged from 41.2 to $159.9 \mathrm{~g}$, with an average of $101.1 \mathrm{~g}$. There were 31 lines with 100 seed weight of 80-100 g, 26 lines with 100 seed weight of 100-120 g, and 22 lines with 100 seed weight more than $120 \mathrm{~g}$. Moreover, the seeds of 34, 57, and 38 lines were small, medium, and large, respectively, while 15, 71, 24, 7, 5 , and 7 lines produced seeds that were beige, green, brown, red, purple, and black, respectively (Fig. 3).

\section{Selection of elite faba bean resources}

To ensure genetic diversity, ten of 20 winter hardness lines were selected based on agronomical characteristics such as origin, seed size, seed color, wintering rate, plant height, 100 seed weight, and seed yield per plant (Fig. 4). These lines included two from Iran, Spain, China, and one from India, Peru, and Turkey. We detected two hilum colors among the seeds of line PI 577722, which resulted in this line being sub-divided into PI 577722-1 and PI $577722-2$. The seeds of the selected 10 lines were green (five lines), brown (two lines), beige (one line), purple (one line), and black (one line). The average winter survival rate for the selected elite lines was $74.5 \%$, while the average plant height was $83.5 \mathrm{~cm}$. Also, the average 100 seed weight was $108.1 \mathrm{~g}$ and seed yield per plants was 140 


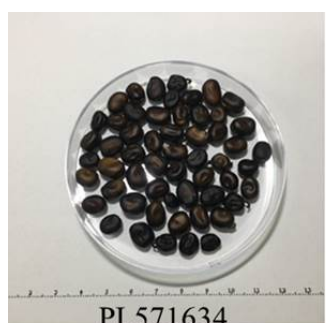

PI 571634

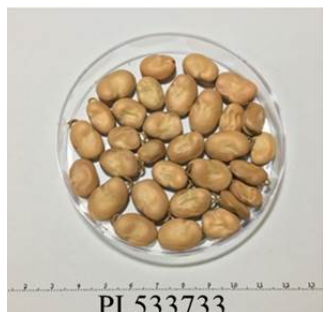

PI 533733

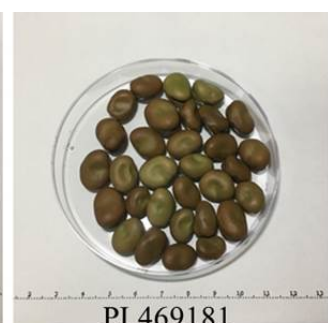

PI 469181

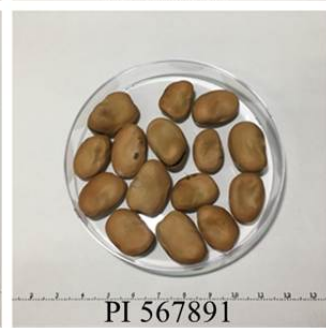

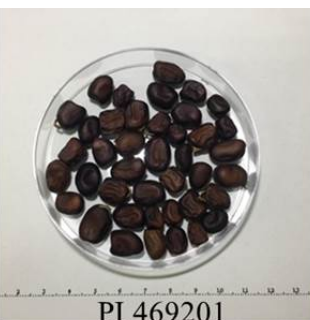

PI 469201

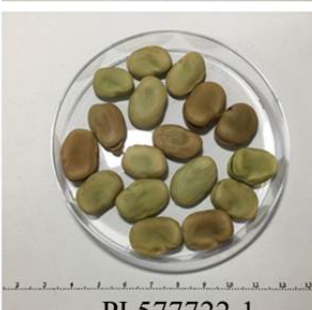

PI 577722-1

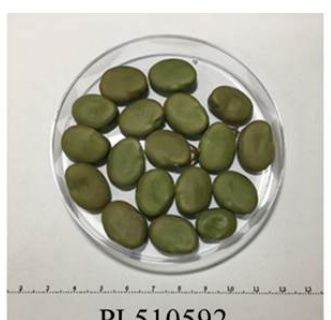

PI 510592

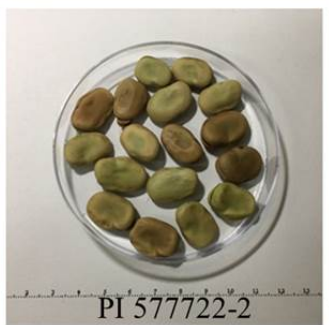

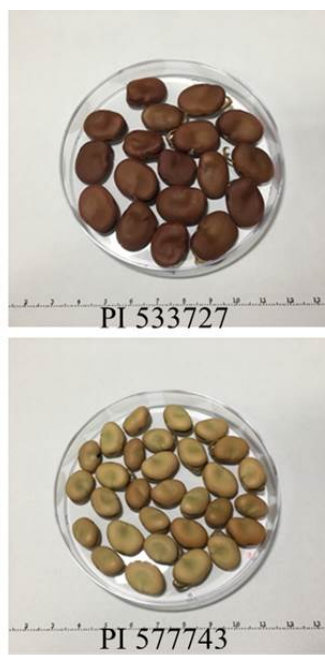

Fig. 4. Selected ten elite faba bean lines with high adaptability to climate in South Korea.

Table 2. Line number, origin and agronomical characteristics of ten faba bean lines selected in this study.

\begin{tabular}{|c|c|c|c|c|c|c|c|}
\hline Line No. & Origin & Seed size & Seed color & $\begin{array}{l}\text { Wintering } \\
\text { rate }(\%)\end{array}$ & $\begin{array}{l}\text { Plant height } \\
(\mathrm{cm})\end{array}$ & $\begin{array}{c}\text { 100-seed } \\
\text { weight }\end{array}$ & $\begin{array}{c}\text { Seed yield } \\
\text { per plant }\end{array}$ \\
\hline PI 271634-2 & India & $\mathrm{S}^{\mathrm{z})}$ & Black & 66.3 & $70.0 \mathrm{~b}^{\mathrm{y})}$ & $61.8 \mathrm{c}$ & $113.7 \mathrm{~cd}$ \\
\hline PI 469181 & Iran & M & Green & 83.3 & $90.0 \mathrm{a}$ & $105.6 \mathrm{~b}$ & $152.0 \mathrm{~b}$ \\
\hline PI 469201-2 & Iran & M & Purple & 73.3 & $68.3 \mathrm{~b}$ & $111.6 \mathrm{~b}$ & $135.7 \mathrm{bcd}$ \\
\hline PI 510592 & Peru & $\mathrm{L}$ & Green & 63.3 & $91.7 \mathrm{a}$ & $135.0 \mathrm{a}$ & $159.3 \mathrm{~b}$ \\
\hline PI 533727 & Spain & $\mathrm{L}$ & Brown & 73.3 & $91.7 \mathrm{a}$ & $122.1 \mathrm{ab}$ & $131.0 \mathrm{bcd}$ \\
\hline PI 533733 & Spain & S & Brown & 60.0 & $91.7 \mathrm{a}$ & $64.8 \mathrm{c}$ & $193.0 \mathrm{a}$ \\
\hline PI 567891 & Turkey & $\mathrm{L}$ & Beige & 83.3 & $73.0 \mathrm{~b}$ & $133.9 \mathrm{a}$ & $107.0 \mathrm{~d}$ \\
\hline PI 577722-1 & China & $\mathrm{L}$ & Green & 86.7 & $76.7 \mathrm{~b}$ & $129.5 \mathrm{a}$ & $129.3 \mathrm{bcd}$ \\
\hline PI 577722-2 & China & $\mathrm{L}$ & Green & 86.7 & $76.7 \mathrm{~b}$ & $129.5 \mathrm{a}$ & $129.3 \mathrm{bcd}$ \\
\hline PI 577743-1 & $\begin{array}{l}\text { The U.S. } \\
\text { Mean }\end{array}$ & $\mathrm{M}$ & Green & $\begin{array}{l}86.3 \\
74.8\end{array}$ & $\begin{array}{l}98.3 \mathrm{a} \\
83.5\end{array}$ & $\begin{array}{l}108.4 \mathrm{ab} \\
108.1\end{array}$ & $\begin{array}{l}138.7 \text { bc } \\
140\end{array}$ \\
\hline
\end{tabular}

${ }^{\mathrm{z})}$ S: Small, M: Medium, L: Large, ${ }^{\mathrm{y})}$ Mean values with different alphabets are significantly different (Tukey's HSD, $P<0.05$ ).

(Table 2)

\section{Comelation analysis}

The Pearson's correlation coefficients are provided in Table 3 . The flowering date was negatively correlated with pod length and 100-seed weight $(P \leq 0.05)$ as well as pod width $(P \leq 0.01)$. Plant height was negatively correlated $(P \leq 0.01)$ with the number of stems and 100 -seed weight. Pod length was positively correlated $(P \leq 0.01)$ with pod width, Seeds per pod, and 100-seed weight. Pod width was positively correlated $(P \leq 0.01)$ with the Seeds per pod and 100 -seed weight.

\section{DISCUSSION}

Autumn-sown faba bean plants offer several advantages over spring-sown faba bean plants, including better use of the available moisture during winter. Additionally, sowing in the autumn helps to avoid the effects of drought conditions toward the end of summer. Furthermore, autumn-sown faba bean plants may exhibit considerable growth in early spring.

However, the main disadvantage of sowing faba been seeds in the autumn is that the germinated seedlings may succumb to freezing stress during the winter (Loss and Siddique 1997). In a previous study conducted in South 
Table 3. Correlation coefficients among agronomic characteristics of autumn-sown 129 faba bean lines.

\begin{tabular}{lcccccc}
\hline \multicolumn{1}{c}{ Character } & Flowering date & Plant height & No. of stems & Pod length & Pod width & Seeds per pod \\
\hline Plant height & 0.069 & - & & & & \\
No. of stems & -0.117 & $-0.284^{* *}$ & - & & & \\
Pod length & $-0.211^{*}$ & -0.055 & 0.019 & - & & \\
Pod width & $-0.279^{* *}$ & -0.162 & 0.017 & $0.701^{* *}$ & - & $0.334^{* *}$ \\
Seeds per pod & -0.099 & -0.060 & -0.032 & $0.663^{* *}$ & - \\
100-seed weight & $-0.211^{*}$ & $-0.338^{* *}$ & 0.049 & $0.477^{* *}$ & $0.626^{* *}$ & 0.134 \\
\hline
\end{tabular}

*Significant at the 0.05 probability level, **Significant at the 0.01 probability level.

Korea, Kim et al. (2001) evaluated the cold tolerance of six faba bean cultivars, and determined that the winter survival rate was less than $40 \%$. Kim (2006) reported that faba bean plants can survive at temperatures as low as $-7^{\circ} \mathrm{C}$, making them suitable for only a few regions in Korea. In the current study, most of the faba bean lines that survived the winter had survival rates that did not exceed $60 \%$, with an average of $35.3 \%$, likely because of a lack of cold-tolerant germplasm and low seed purity. We considered lines to be elite if their winter survival rate was greater than $60 \%$.

Kim (2006) compared four faba bean varieties from Japan regarding the flowering dates of spring-sown and autumn plants. With spring-sown and autumn-sown plants started to flower on April 25 and April 15, respectively. In our study, spring-sown faba bean plants started to flower on April 22, and autumn-sown faba bean plants started to flower on March 29. Thus, the flowering dates of the spring-sown faba bean plants were similar, but the autumn-sown faba bean plants started to flower about half a month earlier in our study.

In previous study, Zong et al. (2006) examined for plant height 5,000 faba bean from the National Genebank of China, the shortest and tallest plants were 10.3 and 201.5 $\mathrm{cm}$ tall, with an average of $78 \mathrm{~cm}$. Zong et al. (2009) also analyzed yield component characteristics. The number of mature seeds per pod ranged from 0.8 to 6.1 , while the 100-dry seed weight ranged from 6 to $240 \mathrm{~g}$ and the grain yield per plant was 1.2-127.0. The pod length was 1.2-18.8 $\mathrm{cm}$, with an average of $6.5 \mathrm{~cm}$. Meanwhile, the pod width ranged from 0.7 to $3.5 \mathrm{~cm}$, with an average of $1.6 \mathrm{~cm}$. Also, Duc et al. (2011) reported that the plant height ranged from 40 to $210 \mathrm{~cm}$ among 250 germplasms. Additionally, $50 \mathrm{had}$ one main stem, while 175 consisted of 1-3 basal stems.
Moreover, the winter-type plants tended to exhibit basal branching. Our data revealed that the plant height among 129 lines ranged from 44.3 to $116 \mathrm{~cm}$, with an average of $78.8 \mathrm{~cm}$. These results imply that the average height of faba bean plants are relatively consistent, but there can be a considerable range. Also, our data revealed that the number of stems among 129 lines ranged from 1.0 to 11.3 , with an average of 5.2. The fact that our faba bean lines produced more stems may have been because of differences in environmental conditions and increased genetic diversity. Therefore, the average pot length, pot width, and number of seeds per pod reported herein were very similar to the data obtained by Zong et al. (2009).

A correlation analysis revealed a negative correlation between the number of stems and plant height. We observed a high correlation between plant height and the number of stems and yield, while there was no correlation between seed size and the number of stems or seeds per pod. These results were consistent with those of a previous study by Kim (2006). The winter survival rate was highly correlated with the number of stems, but there was no correlation between the number of stems and seed size. Genetic factors affected seed size more than environmental factors.

In this study, we selected 10 elite lines suitable for the environmental conditions in Korea according to agronomic characteristics. The hilum color difference among PI 577722 seeds resulted in the separation of line PI 577722 into PI 577722-1 and PI 577722-2. The 10 putative elite lines are expected to improve faba bean cultivation in Korea. Moreover, mutation breeding may generate new varieties with high yields, winter survival rates, and functionality. 


\section{ACKNOWLEDGEMENTS}

This work was supported by Radiation Technology R\&D program (NRF-2017M2A2A6A05018538) through the National Research Foundation of Korea funded by the Ministry of Science and ICT.

\section{REFERENCES}

Chen W, Stoddard FL, Baldwin TC. 2006. Developmental regulation of mannan, arabinogalactan-protein, and pectic epitopes in pistils of Vicia faba (faba bean). Int. J. Plant Sci. 167: 919-932.

Duc G. 1997. Faba bean (Vicia faba L.). Field Crops Res. 53: 99-109.

Duc G, Link W, Marget P, Redden RJ, Stoddard FL, Torres AM, et al. 2011. Genetic adjustment to changing climates: faba bean, p. 269-286. In: SS. Yadav, RJ. Redden, JL. Hatfield, H. Lotze-Campen, AE. Hall (eds.). Crop Adaptation to Climate Change. Wiley-Blackwell, Oxford, UK.

Flores F, Nadal S, Solis I, Winkler J, Sass O, Stoddard FL, et al. 2012. Faba bean adaptation to autumn sowing under European climates. Agron. Sustain. Dev. 32: 727-734.

Hu J, Kwon S-J, Park J-J, Landry E, Mattinson DS, Gang DR. 2015. LC-MS determination of L-DOPA concentration in the leaf and flower tissues of six faba bean (Vicia faba L.) lines with common and rare flower colors. Functional Foods in Health and Disease 5: 243-250.

Kim SK, Kim DH, Kim ES, Song GW, Kang DJ. 2001. Responses of growth and yield as affected by different seedling dates and methods of spring-sown broadbean. Korean Society of Crop Science 46: 176-177

Kim SK. 2006. Studies on establishment of cultural practices and utilization of faba bean (Vicia faba L.). PhD thesis, Gyeongsang National University, Korea.
Lawes D, Bond D, Poulsen M. 1983. Classification, origin, breeding methods and objectives, p.23-76. In: PD. Hebblethwaite (ed.). Faba bean. Butterworth-Heineman.

Link W, Balko C, Stoddard F. 2010. Winter hardiness in faba bean: physiology and breeding. Field Crops Res. 115: 287-296.

Loss S, Siddique K. 1997. Adaptation of faba bean (Vicia faba L.) to dryland Mediterranean-type environments I. Seed yield and yield components. Field Crops Res. 52: 17-28.

Nyoike T, Liburd O. 2010. Effect of living (buckwheat) and UV reflective mulches with and without imidacloprid on whiteflies, aphids and marketable yields of zucchini squash. Int. J. Pest Manag. 56: 31-39.

Randhir R, Shetty K. 2003. Light-mediated fava bean (Vicia $\mathrm{faba}$ ) response to phytochemical and protein elicitors and consequences on nutraceutical enhancement and seed vigour. Process Biochem. 38: 945-952.

Redden R, Zong X, Van Leur J, Wang S, Bao S, Paull J, et al. 2007. Increased productivity of cool season pulses in rain-fed agricultural systems of China and Australia. Final Report ACIAR Project: CSI/2000/035.

Singh A, Dimree S, Khan M, Upadhyaya A. 2009. Agronomic Evaluation of faba bean (Vicia faba L.) performance under impending climate change situation. National Symposium on Recent Global Developments in the Management of Plant Genetic Resources. Indian Society of Plant Genetic Resources, New Delhi, India. pp. 171-179.

Tachibana Y. 1981. Control of aphid-borne viruses in faba bean by mulching with silver polyethylene film. Fabis Newsletter 3: 56.

Zong X, Cheng X, Wang S. 2006. Food legume crops, p. 406-479. In: D. Yuchen, Z. Diansheng (eds.). Crops and its relative species in China-Grain crops. China Agriculture, Beijing.

Zong X, Liu X, Guan J, Wang S, Liu Q, Paull JG, et al. 2009. Molecular variation among Chinese and global winter faba bean germplasm. Theor. Appl. Genet. 118: 971-978. 